INTERNATIONAL JOURNAL OF RESEARCHES IN BIOSCIENCES, AGRICULTURE AND TECHNOLOGY

(C) VISHWASHANTI MULTIPURPOSE SOCIETY (Global Peace Multipurpose Society) R. No. MH-659/13(N) www.vmsindia.org

\title{
MICROWAVE ASSISTED SYNTHESIS, STRUCTURE, SPECTRAL CHARACTERIZATION AND BIOLOGICAL STUDIES OF (E)-N'-(4- FLUORO BENZYLIDENE) HYDRAZINECARBOTHIOHYDRAZIDE
}

\author{
A. M. Nalawade 1 , R. A. Nalawade 1,2 , B. S. Londhe $^{3}$, \\ N. L. Tarwal ${ }^{1}$ and R. V. Shejwal ${ }^{1}$ \\ ${ }^{1}$ Lal bahadur Shastri college Satara, India, ${ }^{2}$ Shivaji university Kolhapur, India. \\ ${ }^{3}$ Karmaveer Bhaurao Patil Mahavidyalaya,, Pandharpur, Maharashtra, INDIA \\ ranalawade12@gmail.com
}

\begin{abstract}
:
Now a days eco-friendly green synthetic methodologies are in great demand. New Schiff's base derivative of thiocarbonohydrazide (E)-N'-(4-fluorolbenzylidene) hydrazinecarbothiohydrazide was synthesized by condensation of thiocarbonohydrazide with 4-Fluoro Benzaldehyde under microwave irradiation without catalyst under solvent free condition, as a green chemistry approach. Within few minutes reaction proceed selectively giving high yields of the product. The structures of products was confirmed by physical and spectral analysis. New Schiff's base derivative of thiocarbonohydrazide shows antibacterial activity against $S$. aureus and $E$. coli and antifungal activity against A. niger and Rhizopus spe. The compound is biologically active in very low concentration. Molar conductance values in DMSO indicate the non electrolytic nature of the compound.

Keyw ords: Microwave irradiation, thiocarbonohydrazide, green synthetic methodologies, Schiff's base
\end{abstract}

\section{Introduction:}

Schiff bases are condensation products of primary amines with carbonyl compounds and they were first reported by Schiff in 1864 . The common structural feature of these compounds is the azomethine groupwith a general formula $\mathrm{RHC}=\mathrm{N}-\mathrm{R} 1$, where $\mathrm{R}$ and $\mathrm{R} 1$ are alkyl, aryl, cyclo alkyl or heterocyclic groups which may be variously substituted. These compounds are also known as anils, imines or azomethines. Several studies [1-7]showed that the presence of a lone pair of electrons in an sp2 hybridized orbital of nitrogen atomof the azomethine group is of considerable chemical and biological importance. Because of the relative easiness of preparation, synthetic flexibility, and the special property of $\mathrm{C}=\mathrm{N}$ group, Schiff bases are generally excellent chelating agents,[8-11] especially when a functional group like $-\mathrm{OH}$ or $-\mathrm{SH}$ is present close to the azomethine group so as to form a five or six membered ring with the metal ion. Versatility of Schiff base ligands and biological, analytical and industrial applications of their complexes make further investigations inthis area highly desirable.

Microwave mediated synthesis has played an important role in organic synthesis over the last decade [12,13]. Seipel et. al.[14] reported that the microwave assisted reaction times are eighty times faster than the conventional heating reaction times and these reactions are more energyefficient than those which use conventional heating. Microwave heating provides better heating efficiency, high rate of reaction, energy and better quality products and therefore it is of interest to use microwave mediated reactions in organic synthesis.

The Schiff bases derived from thio carbonohydrazide are known to exhibit diverse activities like antibacterial [15], anticarcinogenic [16], antiviral [17], herbicidal [18] and antifungal [19] activities. In the present communication, we are reporting the microwave mediated synthesis of (4-fluoro B)HCT under microwave irradiation without catalyst under solvent free condition. (4-fluoro B)HCT was identified by spectral (Uv-visible, IR, NMR and

GC-MS), X-ray diffraction and thermal analysis.

\section{EXPERIMENTAL:}

\section{Instrumentation-}

All chemicals used were of analytical grade, from SD Fine. IR spectra was recorded on Bruker FT- IR spectrophotometer by using $\mathrm{KBr}$ pellets technique. ${ }^{1} \mathrm{HNMR}$ was recorded on Bruker AMX $200 \mathrm{MHz}$ spectrophotometer by using DMSO as solvent. Mass spectra were recorded on YOKUDELNA-ES ${ }^{+} 2000$. The microanalysis of $\mathrm{C}, \mathrm{H}$, and $\mathrm{N}$ were estimated by elemental analyzer (Perkin Elmer 2400), at SAIF, CDRI, Lucknow, India. The UV-visible spectra were recorded in amyl acetate solvent on Beckman DU-64 spectrophotometer with quartz cells of $1 \mathrm{~cm}$ path length. Microwave mediated reaction was carried out in conventional 25 DLX microwave oven.

\section{Synthesis of Schiff base}

It is two step manufacturing process.

a. Preparation of thiocarbohydrazide (TCH) - It is synthesized by various methods [2022]; 
b. one of them is [22] as follows.

Two moles of hydrazine hydrate are refluxed for two hours in an aqueous medium with one mole of carbon disulphide to give thiocarbohydrazide

(TCH).

$$
\mathrm{H}_{2} \mathrm{~N} \cdot \mathrm{NH}_{2} \cdot \mathrm{H}_{2} \mathrm{O}+\mathrm{CS}_{2} \longrightarrow \mathrm{H}_{2} \mathrm{~N}>^{\mathrm{HN}} \prod_{\mathrm{S}}^{\mathrm{NH}}>\mathrm{NH}_{2}
$$

b Microwave mediated synthesis of (E)-N'-14fluorolbenzylidene) hydrazinecarbothiohydra zide Compound was synthesized from thiocarbonohydrazide and 4-fluoro benzaldehyde, which are taken in equivalent proportion. They were mixed well and placed in small conical flask at room temperature. The mixture was then exposed to microwave irradiations with $30 \mathrm{sec}$. pause at $100-700 \mathrm{~W}$. Separate out the product and recrystallize with ethyl alcohol. Completion of reaction was tested by single spot TLC. After completion of reaction the solid obtained was recrystallized from hot alcohol.<smiles>NNC(=S)NN=Cc1ccc(F)cc1</smiles>

\section{Biological Evaluation}

\section{Antibacterial and antifungal activity}

Antibacterial and antifungal activity of (4-fluoro B)HCT was tested by serial dilution technique [23]. Eight test tubes containing $5 \mathrm{ml}$ of sterile nutrient / sabouraud broth were inoculated with $0.02 \mathrm{ml}$ of $24 \mathrm{~h}$ old culture of bacteria $S$. aureus and $E$. coli and fungi A. niger and Rhizopus spe.

respectively. Different amounts of (4-fluoro B)HCT in ethanol were aseptically added with the help of sterile pipettes from the stock solution $100 \mu \mathrm{g} / \mathrm{ml}$ to $5 \mathrm{ml}$ quantities of respective media so as to reach the concentration from $1 \mu \mathrm{g} / \mathrm{ml}$ to $50 \mu \mathrm{g} / \mathrm{ml}$. All test tubes were inoculated at $37^{\circ} \mathrm{C}$ and at room temperature for bacteria and fungi respectively. Test tubes inoculated with organism were observed for presence of turbidity after $24 \mathrm{~h}$ and $48 \mathrm{~h}$ respectively. The lowest concentration of (4fluoro B)HCT inhibiting the growth of organism was determined as MIC value

\section{Results and Discussion:}

The microwave irradiated synthesis of (4-fluoro B)HCT is completed in a couple of minutes ( $5 \mathrm{~min}$ ) giving $75 \%$ yield. The compound (4-fluoro B)HCT is colorless crystalline solid having sharp melting point $188^{\circ} \mathrm{C}$ and soluble in common organic solvents. The compound MBHCTH gave satisfactory $\mathrm{C}, \mathrm{H}, \mathrm{N}$ and $\mathrm{S}$ analyses data. The observed and calculated \% of $\mathrm{C}, \mathrm{H}, \mathrm{N}$ and $\mathrm{S}$ in the (4-fluoro B)HCT were found that C45.30(45.28), H- 5.76 (5.76) , N- 26.41 (26.42) ,S-15.10(15.09)

\section{Spectral analysis}

U.V.-visible spectral data of the (4-fluoro B)HCT was recorded in amyl acetate solution. There was several intense absorptions bands in the visible and ultraviolet regions. These wide range bands seem to be due to both the $\Pi \rightarrow \Pi^{*}$ and $\mathrm{n} \rightarrow \Pi^{*}$ of benzene ring or azomethine ($\mathrm{C}=\mathrm{N})$ groups [24-26]. The bands at the 216-297 $\mathrm{nm}$ region are assigned to intramolecular $\Pi \rightarrow \Pi^{*}$ transitions and the bands at the $321-410 \mathrm{~nm}$ are attributed to $n \rightarrow \Pi^{*}$ transitions of benzene ring or azomethine $(-\mathrm{C}=\mathrm{N})$ groups. The band at $382 \mathrm{~nm}$ corresponds to the transition of azomethine group[27].

IR $(\mathrm{KBr}) \mathrm{cm}^{-1}: \mathrm{C}=\mathrm{N}$ 1613, and $\mathrm{N}-\mathrm{H} 3266$ and 3153.

1HNMR (DMSO) $\delta \mathrm{ppm}: 11.64$ (s, 1H, NH). 11.33 (s, 1H, NH).

7.29-7.1 (m, 4H ,Aromatic), 3.50-3.43 (d, $\left.2 \mathrm{H}, \mathrm{NH}_{2}\right), 7.95$ (s, $\left.1 \mathrm{H}, \mathrm{CH}\right), 2.3\left(\mathrm{~s}, 3 \mathrm{H}, \mathrm{CH}_{3}\right)$; Mass: 208.06.

\section{Antibacterial and antifungal Activities}

The compound (4-fluoro B)HCT has been tested for the evaluation of antibacterial activity against S.aureus and E. coli and antifungal activity against $A$. niger and Rhizopus spe. The MIC values for the compound MBHCTH lie in the range $8-10 \mu \mathrm{g} / \mathrm{ml}$ for antibacterial activity and $3-5 \mu \mathrm{g} / \mathrm{ml}$ for antifungal activity. The compound (4-fluoro B)HCT exhibits prominent antifungal activity than antibacterial activity.

\section{Conclusion:}

Microwave mediated synthesis of (4-fluoro $\mathrm{B}) \mathrm{HCT}$ is a convenient and rapid process resulting in good yield of the expected product. (4-fluoro B)HCT is obtained without catalyst under solvent free condition, as a green 
chemistry approach The reaction rate of MBHCTH is too much faster than the rates of conventional method for synthesis of Schiff bases. The compound MBHCTH exhibit good antibacterial activity against $\mathrm{S}$. aureus and E.coli and antifungal activity against $A$. niger and Rhizopus spe.. It shows better antifungal activity than antibacterial activity.

\section{References:}

[1] P. Singh, R. L. Goel and B. P. Singh, J. Indian Chem. Soc., 1975, 52, 958.

[2] B. F. Perry, A. E. Beezer, R. J. Miles, B. W. Smith, J. Miller and M. G. Nascimento, Microbois., 1988, 45, 181.

[3] A. Elmali, M. Kabak and Y. Elerman, J. Mol. Struct., 2000, 477, 151.

[4] P. R. Patel, B. T. Thaker and S. Zele, Indian J. Chem., 1999, 38 A, 563.

[5] M. Valcarcel and M. D. Laque de Castro, "Flow-Throgh Biochemical Sensors", Elsevier, 1994, Amsterdam.

[6] U. Spichiger-Keller, "Chemical Sesors and Biosensors for Medical and Biological Applications", Wiley-VCH,1998, Weinheim.

[7] J. F. Lawrence and R. W. Frei, "Chemical Derivatization in Chromatography", Elsevier, 1976, Amsterdam.

[8] S. Patai, Ed., "The Chemistry of the CarbonNitrogen Double Bond", J. Wiley \& Sons, 1970, London.

[9] E. Jungreis and S. Thabet S, "Analytical Applications of Schiff bases", Marcell Dekker, 1969, New York.

[10] Metzler C M, Cahill A and Metzler D E, J. Am. Chem. Soc., 1980, 102, 6075.

[11] G. O. Dudek and E. P. Dudek, Chem. Commun., 1965. 464.

[12] P. Lidstrom, J. Tierney, B. Wathey, J. Westman, Tetrahedron 57 (2001) 9225.
[13] P. Nilsson, K. Olofsson, M. Larhed, "Microwave-assisted and metal catalyzed coupling reactions" in microwave methods in organic synthesis, ed. M. Larhed and K. Olofsson Springer, Berlin 266 (2006) 103.

[14] K. R. Seipel, Z. H. Platt, M. Nguyen, A. W. Holland, J. Org. Chem. 73 (2008) 4291.

[15] Baseer, MA.; Jadhav, V.D.; Phule,R.M.; Archana, Y.V.; Vibhute, Y.B. Orient. J. Chem. 2000;16: 553.

[16] Moubaraki,B.; Murray K.S.;Ranford ,J.D.; Xu, X.Y. Chem. Commun., 1998; 353.

[17] Blumenkopf, T.A.; Harrington, J.A.; Koble, C.S.; Bankston, D.D.; Morrsion, R.W.; Bigham, E.C.; Styles, V.L.; Spector, T. J. Med. Chem, 1992; 16: 2306.

[18] Pathak, P.; Jolly, V.S.; Sharma, K.P. Orient. J. Chem. 2000; 16: 161.

[19] Chohan ZH, Pervez H, Khan KM, Supuran CT. J. Enzyme Inhib. Med. Chem. 2005; 20:81

[20] Kurzer F, Wilkinson M, Chem. Rev., 1969, 113

[21] Authenrith \& Hefner, Ber. , 1925,58,2151

[22] Audrieth, J. Org. Chem., 1954, 19, 733,

[23] D. I. Spooner, G. Sykes, "Methods in Microbiology", Academic, London, (1972).

[24] Sacconi L, Coord. Chem. Rev., 1966, 1, 126.

[25] Chen Z, Wu Y, Gu D, Gan F, Dyes and Pigments, 2008, 76,624.

[26] Carlin R.L. (Ed.), Transition Metal Chemistry, Vol. 1,Marcel Dekker, Inc., New York, 1965, p. 239.

[27] ABP. Lever, Inorganic Electronic Spectroscopy, 2nd Ed., Elsevier; Amsterdam, 1984. 